\title{
FEMALE STEREOTYPES IN ROMANIAN ADVERTISING: AN INTERPRETATIVE CONTENT ANALYSIS
}

\author{
Alexandra UJICĂ \\ Babeș-Bolyai University, Romania \\ Raluca BĂBUT \\ Babeș-Bolyai Unniversity, Romania
}

\begin{abstract}
Advertising, by its accessibility, is incredibly powerful in spreading stereotypical representations. The way women are portrayed in advertising in different countries and cultures has been a subject of research for more decades. The paper aims to examine the way women are portrayed in advertising campaigns in Romania. The study focuses on finding the stereotypes used and their characteristics by qualitatively analyzing ads from brands' YouTube channels. We identified seven stereotypes and the analysis shows that women portrayals are idealized in Romanian advertising. Although there are some modern approaches to the representations, ads do not reflect contemporary female roles. The most frequent stereotype is the Next-Door Woman, a stereotype that emphasis on the cuteness of the woman, not on her intelligence. Romanian brands' advertising lacks campaigns promoting women empowerment.
\end{abstract}

Keywords: female stereotypes, women portrayal, advertising, Romania

JEL classification: M31, M37

\section{Introduction}

Advertising, a multifaceted phenomenon, is a significant part of everyday life. Beyond the communication and information function, it also has a social role. Advertising messages indirectly communicate information on generally accepted rules, attitudes, and social roles to consumers. Thus, advertising enhances the social integration of individuals, facilitates universal knowledge of values and provides patterns of social behavior (Arens, 2013). The relationship between advertising and society is widely discussed. On the one hand, advertising is considered

\footnotetext{
* Corresponding author. Address: Department of Marketing, Faculty of Economics and Business Administration, Babeș-Bolyai University, Cluj-Napoca, Romania, 400591 Th. Mihali Street 58-60, Tel. +40 264 418655, Fax. +40 264 412570, alexandra.ujica@stud.ubbcluj.ro
} 
a "mirror" of society reflecting dominant values that already exist. (Holbrook, 1987). On the other hand, advertising has the power to induce and shape values for consumers so it becomes a "mold" of the society (Pollay, 1987).

Advertising messages reflect and build the cultural values of the dominant groups, reflecting and capitalizing on stereotypes, in general, and gender, in particular. As a social media agent with high power among consumers, there are concerns about the distorted way in which the social and professional image and roles of women and men are presented. Women and men are often portrayed in advertising in the form of gender stereotypes that create in the viewer's mind conventional models of the interaction between genders and their roles (Goffman, 1979; Schroeder \& Zwick, 2004). Stereotypes offer a simplified version of the world that can limit the possibilities of self-realization, especially for those who belong to stereotypical groups (Knoll et al., 2011).

Advertising makes an unequivocal contribution to gender inequality by promoting sexism (Kilbourne, 1999). This ongoing trend that places women in lower positions is used in advertising to describe traditional clichés by which women have a predominantly decorative role in society, although they manifest their potential and abilities (Plakoyiannaki \& Zotos, 2009). Advertising messages feature women with perfect body shapes, creating almost impossible ideals (Cortese, 1999).

According to a SheKnows poll, $91 \%$ of respondents believe the way women are portrayed in advertising has a direct impact on girls' self-esteem. Moreover, $94 \%$ of respondents believe portraying women as sex symbols in ads is harmful (Stampler, 2014).

Changing the structure of roles in the family and the workforce has led to significant changes in female and male roles. There is an important research area that explores the degree and the way advertising reflects accurately the contemporary roles of women and men (Plakoyiannaki \& Zotos, 2009). For a long period of time, women and men were depicted in advertising in traditional roles, but recent data indicate a shift towards more positive role portrayals (Grau \& Zotos 2016).

Over the past 60 years, gender stereotypes have been a subject of research around the world. Most of the studies concentrated on the women and men portrayals in print and television. Some studies also did comparative analyses in different cultural contexts (Tsichla, 2020). Even though consumers are spending more and more time online and on social media, little research has examined gender portrayals in online platforms (Grau \& Zotos, 2016). The current study aims to provide recent evidence on female role portrayals in video ads available on the brands' YouTube channels drawing insights from the Romanian market. A former communist country, Romania offers an interesting context for studying female stereotypes because the society has relatively clear rules about how a person should behave according to his/her gender. Stereotypes are present in human interactions, but they are also widespread in the media and advertising (Grunberg, 2005). Romania ranks in 2020 in the 26th place in the EU in terms of the Gender Equality Index, with lower scores than the EU average in all areas (EIGE, 2020). These show us that gender disparities are affecting the social and professional status of women in Romania. Romanian reality is countered by the EU's efforts to an egalitarian society (European Parliament, 2021) and by a series of advertising campaigns of multinational brands (e.g., Dove, Pantene, Always, Nike) promoting female empowerment and personal freedom (Grau \& Zotos, 2016). 


\section{Literature Review}

Stereotypes are defined as exaggerated beliefs associated with a social category (Allport, 1954). A stereotype is a preconceived opinion, a cliché largely independent of individual reactions produced by an unscientific generalization (Chelcea, 2016). According to Eisend (2009), stereotypes can lead to simplified conceptions, expectations and judgments that can restrict the opportunities of subjects from a social category that has already been stereotyped. Depending on the content, stereotypes can be positive or negative. Positive stereotypes refer to those favorable subjective beliefs about members of a particular social group, a membership that gives them advantages, appreciation or even superiority (Czopp et al., 2015). Negative stereotypes refer to those negative traits and characteristics that are attributed to a social group and, by implication, to its members (Voices, 2014). Stereotypes can also be classified according to social category: gender, sex, ethnicity, age, sexual orientation, religion, occupation (Moraru, 2009).

Gender stereotypes are beliefs that are universally recognized as valid about roles, psychological characteristics and behaviors closely related to the person's gender (Browne, 1998).

Deaux \& Lewis (1984) argue that gender stereotypes have four different and independent components: character descriptors (affirmation of one's individuality, care for others), physical characteristics (hair length, height), roles (leader, childcare) and occupational status (housewife, driver). Each of these components is associated with a version, either feminine or masculine. Female stereotypes have been used in advertising, both in campaigns for women and men, since the second half of the 18th century. They are used in advertising under the argument that potential buyers can identify themselves in these portrayals leading to increased effectiveness of the ad and therefore to increased sales (Zhou \& Chen, 1997).

The way women are portrayed in advertising became a topic of debate in the early 1960s at the same time as the feminist movement. Studies carried out at the time revealed significant differences between the image of the woman in advertising and her real role in society. According to Courtney \& Lockeretz (1971), the woman appears in advertising, predominantly, in inferior situations: as a housewife, depending on a man, as a sexual object or deprived of decision-making capacity.

Erving Goffman's study in the late 1970s highlights a culturally infantilized woman and ritually subordinate to the man. Based on a coding system that became a benchmark, Goffman (1979) identified several trends in American magazine advertisements: women's height exceeded by men's; women's hand-touching are delicate, cosseted and never determined and capable of manipulating objects; women receive instructions to use products from men and girls from boys; the gaze and face of women are directed towards the man; the woman often lies on a bed or floor; the look of women is lost and dreamy; women are presented in a mental state of confusion or overwhelmed by the social situation.

Over time, the portrayal of women in advertising has evolved more slowly than the pace at which women have transformed from a housewife to a professional whose voice has gained authority in both the family and society (Gilly et al., 1998). Even today seems that advertising not only does not reflect contemporary roles, but it emphasizes roles that no longer exist in today's society (Zotos \& Tsichla, 2014). Recent studies show that gender stereotypes are still present in advertising 
in many countries (Eisend, 2009, Grau \& Zotos, 2016). The most common female stereotypes are occupational ones (Eisend, 2009), women being portrayed as young ladies, using household products, staying at home, and having dependent roles (Knoll et al., 2011).

Literature that examines female portrayal in advertising (Lysonski, 1985; Mitchell \& Taylor, 1990; Plakoyiannaki et al., 2008; Plakoyiannaki \& Zotos, 2009) shows four stereotype categories: women in traditional roles (dependent and housewives), women in decorative roles (concerned with physical attractiveness and sex objects), women in non-traditional roles (non-traditional activities, career-oriented women, and voices of authority) and women in neutral roles (portrayed as equal to men).

Studies made in Romania about gender stereotypes suggest the existence of a conservative pattern of gender. There are stereotypical approaches to what women do, who they are, and what women want that still prevail. Thus, the leading roles that advertising highlights are: the woman - housewife, the woman - sexual object, the woman - difficult to please, the woman subjected to imposed beauty patterns or the successful diva, and the mother-woman (Grunberg, 2005). According to a more recent study done by Stoica, Miller, \& Ardelea (2011), women are portrayed in a mix of traditional and modern roles. Yet more traditional stereotypes - women concerned for physical appearance and housekeeping - are still in the majority. Women are promoting domestic products, especially personal, beauty and care products and household cleaning products. They also appear in home settings and inactive roles.

\section{Methodology}

The study aims to identify the female stereotypes in Romanian advertising broadcast on TV channels and social media (YouTube). Also, we want to analyze the roles, activities, language, and context in which women are presented.

To address the objective of the research, we used a qualitative approach, an interpretative content analysis. We choose this method because it allows capturing meaning by disaggregating the text into its constituents' parts and subsequently describing the contents of each component to increase understanding of what is communicated and how (Collis \& Hussey, 2014). The text can be found in books, newspapers, magazines, scientific articles, speeches, official documents, videos, movies, images (Agabrian, 2006).

The selection of the advertisements was based upon three primary criteria. First, we selected brands whose advertising campaigns will be analyzed. The selection of brands was based on the top "100 strongest Romanian brands", made in 2018 by Unlock Market Research. This is a ranking of the brands that Romanian consumers consider the strongest according to the following criteria: the importance of the brand, the degree of use, and its awareness. This classification of Romanian brands is based on the investment of trust and affectivity given to them by consumers without considering commercial or financial indices. These brands belong to the following product categories: bottled water, durable goods, hygiene and care products, alcoholic beverages, dairy products, sweets, and retailers. Second, we selected advertising campaigns that were broadcast between 2017 and 2021, available on the brand's official YouTube channel. Third, advertisements had to contain a female character with a significant role. For each advertising campaign, 
we selected only one ad because the stereotype portrayed is the same. A total of 60 advertising campaign that met these criteria was used in the study (Table 1).

Table 1: Advertising campaigns

\begin{tabular}{|c|c|c|}
\hline $\begin{array}{l}\text { Product } \\
\text { Category }\end{array}$ & Brand & Advertising Campaign (2017-2021) \\
\hline \multirow[t]{4}{*}{ Bottled water } & Borsec & $\begin{array}{l}\text { Borsec, the Source of Health and Energy (Borsec, izvor de sănătate și } \\
\text { de energie), Let's Wish Abundant Holidays! (Să ne urăm unii altora } \\
\text { sărbători îmbelșugate!), Let's Celebrate Together the Great Union (Să } \\
\text { celebrăm împreună Marea Unire); }\end{array}$ \\
\hline & Dorna & $\begin{array}{l}\text { Drink Dorna, Do Good (Bei Dorna, faci bine), Come On Out! (Hai pe- } \\
\text { afara!), Shout for Life (Strigăt de viață); }\end{array}$ \\
\hline & $\begin{array}{c}\text { Aqua } \\
\text { Carpatica }\end{array}$ & $\begin{array}{l}\text { Caroling Romania (Colindăm România), AQUA Carpatica Kids (AQUA } \\
\text { Carpatica Kids); }\end{array}$ \\
\hline & Bucovina & $\begin{array}{l}\text { Find The Way To Nature, Find The Way To Yourself (Regăsește } \\
\text { drumul spre natură, regăsește drumul spre tine); }\end{array}$ \\
\hline \multirow[t]{4}{*}{ Durable goods } & Arctic & $\begin{array}{l}\text { Family Is Your Business (Familia este business-ul tău), The Arctic } \\
\text { Effect on the Spirit (Efectul Arctic asupra spiritului), Functions in Your } \\
\text { Life (Funcții din viața ta); }\end{array}$ \\
\hline & Allview & Technology with a Soul (Tehnologie cu suflet); \\
\hline & Savana & What's the Deal with Teflon? (Care-i treaba cu Teflonul?); \\
\hline & Policolor & Beginners, they are helped by the paint (Începători, îi ajută vopseaua); \\
\hline \multirow[t]{5}{*}{$\begin{array}{l}\text { Hygiene and } \\
\text { care products }\end{array}$} & Gerovital & $\begin{array}{l}\text { Gerovital Beauty - The Most Beautiful Film Is Your Life (Gerovital } \\
\text { Beauty - Cel mai frumos film este chiar viața ta!), Gerovital H3 } \\
\text { Evolution, Gerovital Treatment (Gerovital Tratament), Gerovital H3 } \\
\text { Hyaluron (Gerovital H3 Hialuron); }\end{array}$ \\
\hline & Dero & There's One for Two ( $E$ unul pentru doi); \\
\hline & Farmec & $\begin{array}{l}\text { Farmec from the Heart (Farmec din suflet), Farmec Depilatory (Farmec } \\
\text { Depilatoare), Beauty and Trust Are Grown in the Family (Frumusețea } \\
\text { și încrederea se cultivă în familie); }\end{array}$ \\
\hline & Elmiplant & $\begin{array}{l}\text { True Beauty Is Inspired by Nature (Adevărata frumusețe este inspirată } \\
\text { din natură), Elmiplant DETOX, Elmiplant SUN, Elmiplant Mult- } \\
\text { COLLAGEN; }\end{array}$ \\
\hline & Triumf & Your Cleaning Experts (Experții tăi în curățenie); \\
\hline \multirow[t]{5}{*}{$\begin{array}{l}\text { Alcoholic } \\
\text { beverages }\end{array}$} & Ursus & $\begin{array}{l}\text { What Begins with URSUS, Ends Epic (Ce începe cu URSUS se } \\
\text { termină epic), URSUS Untold; }\end{array}$ \\
\hline & Timișoreana & Tradition Goes On (Tradiția merge mai departe); \\
\hline & Cotnari & This Is COTNARI Wine (Acesta-i vinul de COTNARI); \\
\hline & Bergenbier & This Is Cotnari Wine (Răcorim România!); \\
\hline & Ciuc & New Ciuc Radler (Noul Ciuc Radler); \\
\hline \multirow[t]{4}{*}{ Dairy products } & Napolact & $\begin{array}{l}\text { Napolact Challenges Us to Have Weekend Mornings Every Day! } \\
\text { (Napolact ne provoacă să avem dimineți de weekend în fiecare zi!), } \\
\text { Napolact BIO, Invite the Quiet at Your Table! (Poftește tihna la masa ta!); }\end{array}$ \\
\hline & Covalact & $\begin{array}{l}\text { Covalact BIO, Too Good, Too Like in the Countryside (Prea bun, prea } \\
\text { ca la țară); }\end{array}$ \\
\hline & La Dorna & Your Creative Help in the Kitchen (Ajutorul tău creativ în bucătărie); \\
\hline & Zuzu & $\begin{array}{l}\text { Zuzu Divine - Divinely Fine (Zuzu Divin - divin de fin), Discover Dolce } \\
\text { Vita! (Descoperă la Dolce Vita!); }\end{array}$ \\
\hline \multirow[t]{4}{*}{ Sweets } & Heidi & Non-boring (Neplictisitor); \\
\hline & Joe & JOE Dreams; \\
\hline & Rom & Not This Year (Nu anul ăsta!); \\
\hline & Corso & $\begin{array}{l}\text { \#Corsogood, Be More Corso (Fii mai Corso!), Corso's Ark (Arca lui } \\
\text { Corso); }\end{array}$ \\
\hline Retailers & Emag & $\begin{array}{l}\text { Genius Days: April 6-8 (Genius Days: 6-8 aprilie), eMAG Genius, } \\
\text { eMAG Genius (Garantat la eMAG), Find More Than You Think } \\
\text { (Găsești mai mult decât crezi); }\end{array}$ \\
\hline
\end{tabular}




\begin{tabular}{|c|c|l|}
\hline $\begin{array}{c}\text { Product } \\
\text { Category }\end{array}$ & Brand & \multicolumn{1}{|c|}{ Advertising Campaign (2017-2021) } \\
\hline \multirow{1}{*}{} & Dedeman & $\begin{array}{l}\text { Where the Story Ends, the Real Life Begins (Unde se termină povestea, } \\
\text { începe viața adevărată); }\end{array}$ \\
\cline { 2 - 3 } & Altex & $\begin{array}{l}\text { Order Water, Juices, Wine and Beer Online from altex.ro (Comandă-ți } \\
\text { online apă, sucuri, vin și bere de pe altex.ro); }\end{array}$ \\
\cline { 2 - 3 } & Mobexpert & $\begin{array}{l}\text { Yours in 5 Minutes (Al tău în 5 minute), Mobexpert for the Apartment } \\
\text { (Mobexpert pentru apartament), Discover the Touch Screens in Mobexpert } \\
\text { Stores (Descoperă ecranele tactile din magazinele Mobexpert); }\end{array}$ \\
\cline { 2 - 3 } & Catena & $\begin{array}{l}\text { Is Stress a Problem? Come to Catena! (Stresul e o problema? Vino la } \\
\text { Catena!), Catena Wishes You a Happy Easter! (Catena vă urează un } \\
\text { Paște fericit!), A Healthy Heart Loves More (O inimă sănătoasă iubește } \\
\text { mai mult). }\end{array}$ \\
\hline
\end{tabular}

Source: Designed by the authors

The coding scheme was developed based on previous studies (Goffman, 1979; Browne, 1998; Plakoyiannaki \& Zotos, 2008; Matthes et al, 2016) with some new categories related to the video advertisements included. The following categories regarding woman portray were included in the analysis: Role, Activities, Product user, Appearance, Verbal language, Body language, Paraverbal language, Clothing description, Interaction with the other characters of the ad, Interaction or positioning with the product, Setting and decor.

\section{Analysis}

\section{The Next-Door Woman Stereotype}

The Next-Door Woman Stereotype is extremely present in Romania being portrayed in $46.67 \%$ of analyzed campaigns. This can be found in commercials for bottled water, durable goods, hygiene and care products, alcoholic beverages, sweets, and retailers. The Next-Door woman is mostly young, but she can also be middle-aged. She has a filiform body or a common physical conformation. She is gentle, smiling, relaxed, and satisfied with her existence. The verbal communication used is colloquial and cordial. In some ads, she does not speak at all, but in others, she supports the entire auditory scenario. The paraverbal communication adapts to the information transmitted, the tone is friendly when addressing the audience or other characters, and exclamatory when presenting the product. Notably, she expresses her own opinions, without being influenced by any other characters and no connotative phrases are used to address her. The body language betrays her joy and delight. After using the product, the woman's well-being is noticed. The hands are used to handle or consume the product and they approach the camera, thus achieving a connection with the viewer. Even when she does not use the product, it is suggested that her pleasant appearance is a result of its use. Women's clothing is most of the time casual. With small exceptions, she wears elegant clothes when talking about special events.

Often this stereotype is portrayed alone in the ad, or there is no interaction between the woman and the other characters. The purpose of the singular portrait is to create a connection with the audience. The other characters have an admiring and friendly attitude towards her. They are by her side, have a protective attitude, and accompany her in the activities she carries out. Although the activities carried 
out by the Next-Door Woman are extremely diverse, from relaxing indoors, to parties, socializing, walking in the park, and arranging meals, they are common activities for the average. The Next-Door Woman appears in the decor of the ordinary house, at the cafe, on the city streets, in the alleys of the park or the club.

\section{The Active Woman Stereotype}

The Active Woman Stereotype can be found in ads for bottled water and sweets categories. This stereotype is pictured in $15 \%$ of the campaigns. The Active Woman is young, filiform, and athletic. Her face is the testimony of a hectic life, but she has the power to smile and rejoice. The facial expressions of these states often appear after consuming the product. Verbal communication is colloquial. The phrases are dynamic to energize the atmosphere, but also exclamations that inspire consumers, or awake their desire for action. The woman's non-verbal communication suggests her energy. Even if it often seems slightly tired at the beginning of the spot, as soon as she consumes the product, the situation changes radically. The paraverbal communication is exclamatory and rhythmic to create an overall atmosphere consistent with the message to be conveyed. The clothing is sporty or casual to allow the woman to freely carry her activities. The woman either does not interact with the other characters, being extremely focused on her activity, or the other characters help her and have an extremely friendly attitude towards her. She consumes the product in each spot and the consumption is an integral part of her activity. The scenes usually take place in nature or on sports fields and in urban areas.

\section{The Mother Stereotype}

The Mother is found in $20 \%$ of analyzed ads. She considers her child the center of the universe and puts herself in second place. She makes sacrifices for their upbringing and care while denying her worth. The Mother is portrayed in a large number of ads. The stereotype can be found in the following analyzed categories: bottled water, hygiene and care products, durable goods, dairy products, and retailers. The woman is generally young, at most middle-aged, and her physical conformations are often common because she is distinguished by childcare and not by appearance. She is always smiling, and her face lights up when she looks at her child. Verbal communication is colloquial, and the phrases are descriptive and exclamatory, most often presenting the benefits of the product or the child's life. Body language suggests her love for the children and how important they are. She uses her hands and arms to initiate contact with them and makes protective gestures. If she seems overwhelmed by the disaster caused by the children, she quickly changes the condition, being helped by the product that brings joy to both her and the children. The paraverbal communication is the testimony of the character's sensitivity, the tone being emotional, friendly, and exclamatory. The clothing is always casual and in pale colors, suggesting that for the Mother, the child is the most important.

There is also an interesting aspect of portrayal with novelty elements, different from the classic stereotype. The woman is helped by the husband to take care of the child, who is part of almost all activities. The woman's activities are related to the development and upbringing of children or caring for the home and she rarely relaxes. The action often takes place inside the house or in their backyard. 


\section{The Sensual Woman Stereotype}

The Sensual Woman Stereotype can be found in around $21 \%$ of analyzed ads for the following categories: hygiene and care products, alcoholic beverages, dairy products, sweets and retailers. The Sensual woman is young or middle-aged. She is filiform, has a low-cut neckline, a bright face and plump lips, most often highlighted with red lipstick, and facial expressions are intensely sensual. The look is piercing, and the smile is, of course, sensual. The voluptuous woman usually has no lines in the commercials, expressing herself through gestures, and the attention is focused on her physical attributes. The connotative language used by the man towards her is noticeable. The paraverbal communication completes the sensual atmosphere, the tone of speech being tempting, sugary. Body language is full of meanings, which is the main method of transmitting the message. The woman caresses her body, has a powerful look that emanates both erotism and mystery. She oscillates between intimate caresses and exuberant, slightly lascivious movements that emphasize her ease and self-confidence.

The woman's clothing is in line with the attitude. She is wearing sensual clothes in bright colors. The woman is admired by the other characters that come to her aid. However, some ads show the superior attitude of the man who tends to see only woman's physical qualities and to objectify her. She sensually uses the product, caressing her body when applying or consuming it sensually. She holds the product in her hand and it is suggested that due to consumption she has also gained sensuality. The Sensual Woman attends parties and events and has romantic encounters.

\section{The Housewife Stereotype}

The Housewife Stereotype appears in $11.67 \%$ of the ads included in the sample for the following categories: hygiene and care products, alcoholic beverages and dairy products. The Housewife is portrayed at all ages and there is no physical pattern, the focus being on housework. The woman's language is colloquial, but there is a great frequency of archaic and regional words, even using of rhymes to transmit the message. The phrases are descriptive, and they present most of the time the product or process of cooking. Body language betrays the importance of housework, she is concentrated, sometimes even worried in fear that something is not perfect. The joy is to be seen on her face after receiving the appreciation of others. Paraverbal communication is observed in tune with this, which is a rhythmic and friendly one. The Housewife's clothing varies from a casual one to a traditional one, and the apron is present almost in every ad, which demonstrates that she takes her role seriously. The interaction with other characters seems to contradict the classical stereotype of women, the lack of man's involvement and his superiority existing in very few ads. Most characters have a friendly attitude towards her, appreciate and recognize her effort. The man helping the woman at home is an element of modernity. The woman uses the product for the fulfillment of household activities, and this gives her an air of superiority. Her activities take place in the dwelling, in the kitchen and the living room for an easy identification of the consumer with the framework; or outside the house, in a traditional yard, to make the transition in the in illo tempore of the old village, an archaic frame enhanced by traditional objects woven with folklore or clay motifs. 


\section{The Natural Beauty Stereotype}

The Natural Beauty Stereotype is found in advertising commercials for hygiene and care products, but also in those for dairy products. This stereotype appears in $13.33 \%$ of the campaigns. The woman is portrayed at all ages, but the emphasis is placed on the bright, smiling face and firm skin. It has fine, angelic features and emanates naturalness, make-up is missing or is very discreet. Verbal communication is colloquial, poetic or even specialized, and the replies are designed to describe the atmosphere or present how the character is feeling after product consumption. Body language suggests admiration of her look, the woman caressing with contentment both the face and the body. Paraverbal communication supports the ingenuous attitude of the woman, the tone being friendly. Most of the time, the woman appears alone in advertising frames. When other characters appear, we notice a slight superiority in man's attitude, but fully respectful towards the woman. The woman's only activity is the consumption or description of the product, all in a décor that wants to create the impression of purity, which makes use of white backgrounds.

\section{The Independent Woman Stereotype}

The Independent Woman Stereotype only appears in $6.67 \%$ of ads and only in those for hygiene and care products. She is portrayed at all ages and all physical conformations, a sign that it matters what she does and not her physical appearance. Verbal communication is colloquial, and the woman speaks knowingly using descriptive phrases. There are also exclamation phrases or ones that show care for the female characters. Paraverbal communication is noticed by the friendly tone, rhymes, or exclamations. The woman body language demonstrates her selfconfidence. She always has smart-casual or uniform clothing. The other characters recognize their expertise and ask for help. She is, generally, portrayed at work. She does not always use the product within the ad, most of the time being emphasized on the results of its use. When she uses it, the professional posture is highlighted. The decor is professional, office or lab, but also the inside of the house.

\section{Discussion}

The Next-Door Woman Stereotype is present in six out of seven studied product categories fact that is similar with the findings of Englis et al. (1994): she promotes a broad range of products. Both this and its high presents in ads makes this type of woman among the most preferred portray used in advertising in Romania. In comparison to other research, we can say that the same pattern is followed. The Next-Door Women have a friendly tone, wear casual clothes and are mostly young which is consistent with Englis et al. (1994). We observed that they not only wear casual clothes, but elegant ones when attending special events, which suggests that she promotes as well some outstanding products. A positive aspect of the portrays' is that the women are equal to men and other characters have a protective attitude towards them.

The Active Woman Stereotype is presented in ads for bottled water and sweets. The portray identified by us is similar to what other studies had found out. 
Stănculescu (2009) also noticed that she has a lot of energy, a hectic life, and she is portrayed in the middle of an action, usually in the city or on the sports fields as in Englis et al. (1994) analysis. In the case of this stereotype as in the case of the Next-Door Woman, the female is helped by others, and they have a positive attitude towards her.

A more traditional portray is the Mother Stereotype which is present in a lot of ads where the product is seen as a saving solution that helps her to cope with her daily activities. Similar to the findings of Kitch (2001) and Eckert \& McConnellGinet (2003), the woman makes sacrifices for her children, her existence is in second place and usually, her interactions are limited to those with the child. Different from the classic stereotype is the fact that she is helped by her husband when it comes to taking care of the children.

A portray in which women are appreciated mainly for their physical characteristics is the Sensual Women Stereotype. This stereotype is presented in a wide variety of product categories from hygiene and care products to alcoholic beverages and dairy products. She is young, filiform, sexy, has extremely sensual facial expressions, and the men usually objectify her and use connotative language towards her. She is wearing sexy clothes in bright colors that leave parts of her body visible to be admired, especially by the male gaze, and she also has romantic encounters. The consumption of the product gives her confidence and makes her gain sensuality. All these elements are consistent with previous research from Goffman (1979), Kitch (2001) and Moraru (2009).

Another traditional portray is the Housewife Stereotype. She is portrayed at all ages and physical conformation because what matters for her is the housework and being recognized for her household skills. Our results are mostly related to previous research because they show the same pattern as those illustrated by Kitterød \& Rønsen (2011). In addition, we also found out some modern elements such as a woman being helped by a man that has a friendly attitude. Particular for Romanian commercials, there are the traditional elements such as wooden objects, folklore motifs or the traditional up-tempo expressions that make the transition to the old and archaic village typical for the Carpatho-Danubian area.

Women portrayed as the Natural Beauty Stereotype distinguish themselves by naturalness. Our research revealed that the accent is put on the bright face and firm skin fact that is in line with previous research from Solomon et al. (1992) and Moraru (2009).

The Independent Woman Stereotype is portrayed in a professional décor, at work being in a uniform or smart-casually dressed. The women are depicted at all ages and physical conformations because the accent is on their career and not on their physical appearance. The others recognize their expertise and they have the power to show their character and intelligence. These findings are connected with the results of previous research made by Hung \& Li (2006), Moraru (2009), Plakoyiannaki \& Zotos (2009) and Popescu et al. (2015). We have identified only one product category, hygiene and care, in which Independent women appear, this stereotype being represented in the same product category as in Bolliger's study (2008). 


\section{Conclusion}

Although we found both modern and traditional portrayals of women in Romanian ads, the traditional ones are still very popular. Women are usually portrayed doing household chores or taking care of the children and are appreciated, especially for their physical appearance. The most common stereotype is the NextDoor Woman, but even though it is a modern portray, it still presents the woman only as pretty and nice, not as an intelligent person.

How the women are pictured entitled us to affirm that females' portrayals are strongly idealized in most of the cases in Romanian advertisements. Women depictions do not capture everyday reality. Although there is an evolution in the portrayal of the woman over time, it does not keep up with its true emancipation. Moreover, we have not found any campaigns to be part of the femvertising mainstream promoting women's talent, freedom and empowerment. So, we can conclude that advertising in Romania does not reflect the contemporary roles of the woman.

\section{Limitations and Future Directions}

The research had several limitations. First, we have analyzed advertising campaigns made by Romanian brands. Second, we considered only ad campaigns that were available on the brands' YouTube channels.

These limitations offer possibilities for further research. For instance, an analysis of all brands present on the Romanian market could be done. Furthermore, content from more social media platforms could be analyzed. These types of research offer the possibility to compare national versus international brand campaigns or to the differences that occur in communication from one social media platform to another. Besides these, another future direction could be to investigate female stereotypes by product category.

\section{References}

Agabrian, M. (2006). Analiza de conținut. Iași: Polirom.

Allport, G. W. (1954). The Nature of Prejudice. Palo Alto: Addison Wesley.

Arens, W. F. (2013). Contemporary Advertising and Integrated Marketing Communications, New York: McGraw-Hill.

Ashmore, R., \& Del Boca, F. (1981). Cognitive Approaches in Stereotyping and Intergroup Behaviour. In D. L. Hamilton, Conceptual approaches to stereotypes and stereotyping (pp. 1-35). Hillsdale: Lawrence Erlbaum Associates.

Bolliger, D. U. (2008). Perceived Gender Based Stereotypes in Educational Technology Advertisements. TechTrends, 52(3), 46-52.

Browne, B. A. (1998). Gender Stereotypes in Advertising on Children's Television in the 1990s: A Cross-National Analysis, Journal of Advertising. Journal of Advertising, 27(1), 83-96.

Chelcea, S. (2016). Psihosociologie aplicată: Publicitatea. Iași: Polirom.

Collins, J. \& Hussey, R., (2014). Business Research - A Practical Guide for Undergraduate and Postgraduate Students. 4th ed. Basingstoke: Palgrave. 
Cortese, A. J. (1999). Provocateur Images of Women and Minorities in Advertising. New York: Rowman and Littlefield.

Courtney, A. E., \& Lockeretz, S. W. (1971). A Woman's Place: An Analysis of the Roles Portrayed by Women in Magazine Advertisements. Journal of Marketing Research, 8(1), 92-95.

Czopp, A. M., Kay, A. C., \& Cheryan, S. (2015). Positive Stereotypes Are Pervasive and Powerful. Perspectives. Psychological Science, 10(4), 451-463.

Deaux, K., \& Lewis, L. (1984). Structure of Gender Stereotypes: Interrelationships Among Components and Gender Label. Journal of Personality and Social Psychology, 46(5), 991-1004.

Eckert, P., \& McConnell-Ginet, S. (2003). Language and Gender. New York: Cambridge University.

Eisend, M. (2009). A Meta-Analysis of Gender Roles in Advertising. Journal of the Academy of Marketing Science, 34(4), 418-440.

Englis, B. G., Solomon, M. R., \& Ashmore, R. D. (1994). Beauty Before the Eyes of Beholders: The Cultural Encoding of Beauty Types in Magazine Advertising and Music Television. Journal of Advertising, 23(2), 49-64.

European Institute of Gender Equality, (2020). Indicele egalității de gen 2020 România. [Online] Available at: https://eige.europa.eu/gender-equality-index/2020/country [Accessed 15 July 2021].

Gilly, M. C., Graham, J. L., Wolfinbarger, M. F., \& Yale, L. J. (1998). A Dyadic Study of Interpersonal Information Search. Journal of the Academy of Marketing Science, 26(2), 83-100.

Goffman, E. (1979). Gender Advertisements. New York: Harper \& Row.

Grau, S. L., \& Zotos, Y. C. (2016). Gender stereotypes in Advertising: A Review of Current Research. International Journal of Advertising, 35(5), 761-770.

Grunberg, L. (coord.) (2005). Mass media despre sexe: aspecte privind streotipul de gen în mass media din România, București: Tritonic.

Holbrook, M. (1987). Mirror, Mirror, on the Wall, What's Unfair in the Reflections on. Journal of Marketing, 51(3), 95-103.

Hung, K. H., \& Li, S. Y. (2006). Images of the Contemporary Woman in Advertising in China: A Content Analysis. Journal of International Consumer Marketing, 19(2), 7-28.

Kilbourne, J. (1999). Deadly Persuasion: Why Women and Girls Must Fight the Addictive Power of Advertising. New York: The Free.

Kitch, C. (2001). The Girl on the Magazine Cover: The Origins of Visual Stereotypes in American Mass Media. Chapel Hill: The University of North Carolina.

Kitterød, R. H., \& Rønsen, M. (2011). Housewives in a dual-earner society. Who is a housewife in contemporary Norway?. Oslo: Statistics Norway.

Knoll, S., Eisend, M., \& Steinhagen, J. (2011). Gender Roles in Advertising: Measuring and Comparing Gender Stereotyping on Public and Private TV Channels in Germany. International Journal of Advertising, 30(5), 867-888.

Lysonski, S. (1985). Role Portrayals in British Magazine Advertisements', European Journal of Marketing 19(7), 37-55.

Matthes, J., Prieler M., Adam, K. (2016). Gender-Role Portrayals in Television Advertising Across the Globe, Sex Roles, 75, 314-327.

Mitchell, P. C. N., Taylor, W. (1990). Polarising Trends in Female Role Portrayal in UK Advertising, European Journal of Marketing 24(5), 41-49.

Moraru, M. (2009). Mit și publicitate. București: Nemira. 
Parlamentul European, Gender Equality Strategy 2020-2025: Parliament's reaction and input, (2021). [Online] Available at: https://www.europarl.europa.eu/news/ro/press-room/20210114IPR95617/genderequality-strategy-2020-2025-parliament-s-reaction-and-input [Accessed 15 July 2021].

Plakoyiannaki, E., \& Zotos, Y. (2009). Female Role Stereotypes in Print Advertising: Identifying Associations with Magazine and Product Categories. European Journal of Marketing, 43(11), 1411-1434.

Plakoyiannaki, E., Mathioudaki, K., Dimitratos, P., \& Zotos, Y. (2008). Images of Women in Online Advertisements of Global Products: Does Sexism Exist? European Journal of Marketing, 83(1), 101-112.

Pollay, R. W. (1987). On the Value of Reflections on the Values in "The Distorted Mirror". Journal of Marketing, 51(3), 104-110.

Popescu, M., Vasilescu, M., Nistor, I. M., \& Medeleanu, M. (2015). Stereotipuri feminine în cultura română. București: RAO.

Schroeder, J. E., \& Zwick, D. (2004). Mirrors of Masculinity: Representation and Identity in Advertising Images. Consumption, Markets and Culture, 7(1), 21-52.

Solomon, M. R., Ashmore, R. D., \& Longo, L. C. (1992). The Beauty Match-Up Hypothesis: Congruence between Types of Beauty and Product Images in Advertising. Journal of Advertising, 21(4), 23-34.

Stampler, L. (2014) Here's How Women Respond to All Those 'Female Empowerment' Ads. [Online] Available at: https://time.com/3502904/heres-how-womenrespond-to-all-those-female-empowerment-ads/ [Accessed 17 July 2021].

Stănculescu, E. (2009). Stereotipurile de gen din perspectiva cogniției sociale. Revista de psihologie, 55(3-4), 213-226.

Stoica, M., Miller, D. W., Ardelea. D. (2011). An examination of gender role portrayals in television commercials in Romania: A gender of nations approach, Journal of Marketing Communications, 17(4), 245-261.

Tsichla, E. (2020). The Changing Roles of Gender in Advertising: Past, Present, and Future, Contemporary Southeastern Europe, 7(2), 28-44.

Unlock Market Research. (2018). Cele mai puternice 100 de branduri româneşti în 2018, Time (September, 11). Retrieved July 10, 2021, from Revista Biz: https://www.revistabiz.ro/cele-mai-puternice-100-de-branduri-romanesti-in-2018/.

Voci, A. (2014). Negative Stereotypes. In M. A. C, Encyclopedia of Quality of Life and Well-Being Research (pp. 4308-4310). Dordrecht: Springer.

Zhou, N., \& Chen, M. Y. (1997). A Content Analysis of Men and Women in Canadian Consumer Magazine Advertising: Today's Portrayal, Yesterday's Image? Journal of Business Ethics, 16(5), 485-495.

Zotos, Y. C., \& Tsichla, E. (2014). Female Stereotypes in Print Advertising: A Retrospective Analysis. Procedia - Social and Behavioral Sciences, 148, 446-454. 